\title{
Potential of Duckweed for Swine Wastewater Nutrient removal and Biomass Valorisation through Anaerobic Co-digestion
}

\author{
Luis Pena ${ }^{1}$, Margarida Oliveira ${ }^{* 2}$, Rita Fragoso ${ }^{3}$, Elizabeth Duarte ${ }^{4}$
}

${ }^{1}$ Instituto Superior de Agronomia, University of Lisbon, Tapada da Ajuda 1349-017, Lisboa, Portugal e-mail: luis.apoloniapena@gmail.com

${ }^{2}$ Escola Superior Agrária de Santarém, Politecnic Institute of Santarém, Quinta do Galinheiro, São Pedro 2001-904, Santarém, Portugal

Linking Landscape, Environment, Agriculture and Food (LEAF), Research Centre, Instituto Superior de Agronomia, University of Lisbon, Tapada da Ajuda 1349-017, Lisboa, Portugal e-mail: margarida.oliveira@esa.ipsantarem.pt

${ }^{3}$ Instituto Superior de Agronomia, University of Lisbon, Tapada da Ajuda 1349-017, Lisboa, Portugal Linking Landscape, Environment, Agriculture and Food (LEAF), Research Centre,

Instituto Superior de Agronomia, University of Lisbon, Tapada da Ajuda 1349-017, Lisboa, Portugal e-mail: ritafragoso@isa.ulisboa.pt

${ }^{4}$ Instituto Superior de Agronomia, University of Lisbon, Tapada da Ajuda 1349-017, Lisboa, Portugal Linking Landscape, Environment, Agriculture and Food (LEAF), Research Centre,

Instituto Superior de Agronomia, University of Lisbon, Tapada da Ajuda 1349-017, Lisboa, Portugal e-mail: eduarte@isa.ulisboa.pt

Cite as: Pena, L., Oliveira, M., Fragoso, R., Duarte, E., Potential of Duckweed for Swine Wastewater Nutrient removal and Biomass Valorisation through Anaerobic Co-digestion, J. sustain. dev. energy water environ. syst., 5(2), pp 127-138, 2017, DOI: http://dx.doi.org/10.13044/j.sdewes.d5.0137

\section{ABSTRACT}

Over the last decades, phytodepuration has been considered an efficient technology to treat wastewaters. The present study reports a bench scale depuration assay of swine wastewater using Lemna minor. The highest observed growth rate obtained in swine wastewater was $3.1 \pm 0.3 \mathrm{~g}_{\mathrm{DW}} \mathrm{m}^{-2} \mathrm{day}^{-1}$ and the highest nitrogen and phosphorus uptake were $140 \mathrm{mg} \mathrm{N} \mathrm{m}^{-2} \mathrm{day}^{-1}$ and $3.47 \mathrm{mg} \mathrm{P} \mathrm{m}^{-2}$ day $^{-1}$, respectively. The chemical oxygen demand removal efficiency in the swine wastewater assay was $58.9 \pm 2.0 \%$. Furthermore, the biomass valorisation by anaerobic co-digestion with swine wastewater was assessed. Results showed a clear improvement in specific methane production rate (around 40\%) when compared to mono-substrate anaerobic digestion. The highest methane specific production, $131.0 \pm 0.8 \mathrm{~mL} \mathrm{CH}_{4} \mathrm{~g}^{-1}$ chemical oxygen demand, was obtained with a mixture containing $100 \mathrm{~g}$ of duckweed per liter of pre-treated swine wastewater. The water-nutrients-energy nexus approach showed to be promising for swine waste management.

\section{KEYWORDS}

Anaerobic co-digestion, Biogas, Biomass production, Duckweed, Lemna minor, Swine slurry.

\section{INTRODUCTION}

Livestock intensive production is one of the main contributors to Greenhouse Gas (GHG) emissions and direct or indirect water pollution. Swine wastewater is widely

\footnotetext{
${ }^{*}$ Corresponding author
} 
known to be a high-strength wastewater with a pollutant organic load, which is much greater than domestic sewage. Therefore, minimising the impact of swine wastewater on the environment is one of the more pressing challenges facing the agriculture industry. Pig farms are facing the need to adopt more sustainable practices in order to mitigate emissions to air, soil and water. In Southern European countries it is common practice to use swine wastewater as an organic fertilizer, contributing for a more sustainable agriculture and livestock production sector [1]. Despite this being a sustainable practice, there are several pig farms that do not have enough agriculture land in its surroundings, being forced to export the surplus swine wastewater for other regions. Whenever this is the case, swine wastewater should be concentrated through solid-liquid separation minimising transportation costs. On the other hand, several technologies have been studied for the treatment of swine wastewater including physico-chemical [2] and biological processes [3].

The conversion of nutrients into valuable plant biomass, in addition to different harvesting conditions was evaluated [4], in order to recycle the nutrients, has drawn an increasing amount of attention. In particular, the subject matters that have drawn attention are on the biomass growth which aims for nutrients recycling as well as on the studies of different harvesting conditions [4]. For instance, the cultivation of wetland plant species (capable of utilizing the excess nutrients) in wastewater has been found to be a great depuration method since 1970's. Not only are these plants able to purify water in a simple, inexpensive and energy-efficient manner, but the biomass produced by the plants can also be used as bioenergy crops [5, 6] or as a source of protein and amino acids [7, 8].

Duckweeds are small, free-floating aquatic plants (Lemnaceas) that grow in lakes, ponds and pools and whose geographical distribution extends throughout the world, except in the Arctic and Antarctic regions. This monocotyledonous family comprises 37 species of five genera (Lemna, Landoltia, Spirodela, Wolffia and Wolffiella), reproducing asexually with fast growth rates [9]. Previously adapted to the culture medium, duckweed efficiently proliferates in nutrient-rich water bodies, reducing nitrogen and phosphorus in the water, thus preventing environmental risks [10]. Also, the ability of duckweed to tolerate high ammonia nitrogen, as well as its nitrogen absorption capacity as ammonium, makes it a suitable model for swine wastewater depuration $[7,11]$. This way, integration of duckweed in wastewater treatment process can effectively contribute both to depuration and biomass production, providing the opportunity for a cost-effective production system. Due to these characteristics, various duckweed species have been well studied in wastewater treatment, such as, agricultural, municipal and industrial wastewaters, not only to recover nutrients [12] but heavy metals [13] or to produce suitable biomass [14] for animal feed and fertilizer [15]. But are these applications economically viable? The truth is that the importance of sustainability, renewable energy and circular economy is considered timely but it was not in the past [16]. The concept of sustainable development led to the exploration of alternative energy sources especially for bioethanol [6] and biodiesel production [17]. In this sense duckweed can be very attractive as an alternative crop due to its excellent growth [18], starch accumulation $[5,19]$ capability and does not compete with food production. Several reports had been focused on the use of duckweed as a feedstock for biofuel production. However, there is a lack of studies considering the use of duckweed for biogas production through codigestion process.

As in Portugal, the most common treatment for swine wastewater includes solidliquid separation followed by lagoon system, the present study simulated the depuration by L. minor growth in the last lagoon with the following objectives:

- Determine growth rate of L. minor; 
- Assess the efficiency of duckweed for nutrients removal from pre-treated swine wastewater;

- Test the applicability of anaerobic co-digestion for biomass valorisation.

\section{MATERIAL AND METHODS}

This study was developed in a closed-cycle farm located in Ribatejo region (Portugal). The farm has about 500 sows, 1,620 nursing pigs and 4,000 growing pigs, and complies with the industrial emissions Directive 2010/75/EC (24 November 2010).

\section{Swine wastewater characterisation}

Swine Wastewater (SW) management system includes a storage tank, solid-liquid separation followed by a lagoon system: 3 anaerobic lagoons (total volume $6,039 \mathrm{~m}^{3}$ ) and 1 facultative lagoon $\left(5,474 \mathrm{~m}^{3}\right)$ after which SW is applied to 213 ha of land belonging to the farm owner. Composite SW samples were collected from the storage tank, under stirring. Samples were pre-treated by sieving to remove coarse materials (PSW) and kept at $4{ }^{\circ} \mathrm{C}$ until they were analysed. Samples were characterised by various water quality parameters (Table 1), including Total Solids (TS), Total Volatile Solids (VS), Total Suspended Solids (TSS), Total Phosphorus (TP), Total Kjeldahl Nitrogen (TKN), Nitrate $\left(\mathrm{NO}_{3}{ }^{-}\right)$, Ammonium $\left(\mathrm{NH}_{4}{ }^{+}-\mathrm{N}\right)$, Chemical Oxygen Demand (COD), according to Standard Methods [20]. The Electric Conductivity (EC), temperature and $\mathrm{pH}$ were measured with pH 340i (WTW, Germany).

Table 1. Pre-treated Swine Wastewater (PSW) characteristics

\begin{tabular}{|c|c|}
\hline Parameter & PSW \\
\hline $\mathrm{pH}$ & $7.8 \pm 0.1$ \\
\hline $\mathrm{EC}\left[\mathrm{mS} \mathrm{cm}{ }^{-1}\right]$ & $9.5 \pm 1.5$ \\
\hline $\mathrm{TS}\left[\mathrm{g} \mathrm{L}^{-1}\right]$ & $7.6 \pm 0.8$ \\
\hline $\mathrm{VS}\left[\mathrm{g} \mathrm{L}^{-1}\right]$ & $4.6 \pm 0.3$ \\
\hline $\operatorname{COD}\left[\mathrm{g} \mathrm{L}^{-1}\right]$ & $8.3 \pm 0.8$ \\
\hline $\mathrm{TKN}\left[\mathrm{g} \mathrm{L}^{-1}\right]$ & $1.2 \pm 0.1$ \\
\hline $\mathrm{NH}_{4}{ }^{+}-\mathrm{N}\left[\mathrm{g} \mathrm{L}^{-1}\right]$ & $0.9 \pm 0.1$ \\
\hline
\end{tabular}

\section{Plant material and experimental conditions}

L. minor was obtained from ponds located in Oeiras, Lisbon area. Following collection, the duckweed was rinsed gently with water and the healthy fronds were acclimatised in laboratory environment with constant temperature $\left(23{ }^{\circ} \mathrm{C}\right)$ under a photoperiod of 12:12 h light/dark (7,500 lux) in plastic aquaria either in Hoagland solution [21] and in $4 \%$ pre-treated swine wastewater $\left(43.6 \mathrm{mg} \mathrm{NH}_{4}^{+}-\mathrm{N} \mathrm{L}^{-1}\right.$ and $8.49 \mathrm{mg} \mathrm{P} \mathrm{L}^{-1}$ ), whose concentration of nitrogen and phosphorus is similar to the facultative lagoon installed at full scale.

Duckweed was cultured in $5 \mathrm{~L}$ plastic container $(28 \times 20 \times 14 \mathrm{~cm})$ at $24 \pm 1{ }^{\circ} \mathrm{C}$, for 10 days, with a photoperiod of 12:12 h light/dark, with light intensity of 7,500 lux. Three batch tests were conducted to evaluate duckweed nutrients uptake, using a $4 \%$ dilution of pre-treated swine wastewater (DWS1, DWS2 and DWS3). Three positive controls using Hoagland solution (DWH1, DWH2, DWH3) and three negatives controls using 4\% diluted swine wastewater without duckweed (S1, S2, S3) were provided. A total of $12 \mathrm{~g}$ of fresh material were inoculated, in the DWS and DWH systems, to cover $80 \%$ of the entire water surface with a single layer of fronds. During the assays, temperature, $\mathrm{pH}$, conductivity, COD and the nutrient concentration were monitored every day. Any water 
lost due to evaporation was replaced every day throughout the experiments with distilled water.

Duckweed growth was evaluated during the assays. To measure duckweed Fresh Weight (FW), the surplus water was removed and subsequently the biomass was weighted. To measure the Dry Weight (DW), the samples were dried at $60{ }^{\circ} \mathrm{C}$ until the weight was constant. The content of the organic Carbon (C) in the dry duckweed was measured in Skalar Primacs ${ }^{\mathrm{sc}}$ TOC analyser equipment. The Nitrogen $(\mathrm{N})$ and phosphorus content were measured according to reference methods [22]. The growth rate and nutrient uptake rate were determined as follows:

Biomass yield $\left(\mathrm{g}_{\mathrm{DW}} \mathrm{m}^{-2} \mathrm{day}^{-1}\right)=$ plant densities $\left(\mathrm{g} \mathrm{m}^{-2}\right) \times$ relative growth rate $\left(\right.$ day $\left.^{-1}\right)$

$$
\text { Nutrient uptake rate }\left(\mathrm{g} \mathrm{m}^{-2} \text { day }^{-1}\right)=\text { biomass yield }\left(\mathrm{g}_{\mathrm{DW}} \mathrm{m}^{-2} \text { day }^{-1}\right) \times \text { nutrient concentration }\left(\mathrm{g} \mathrm{g}_{\mathrm{DW}}{ }^{-1}\right)
$$

\section{Statistical analysis}

All treatments were performed in triplicate. Analysis Of Variance (ANOVA) was used to determine the effect of culture medium on duckweed growth and nutrients uptake. Means were compared by the Tuckey's test at a 5\% significance level.

First-order kinetic equations were used to describe COD, TP and $\mathrm{NH}_{4}{ }^{+}-\mathrm{N}$ removal from assays. The kinetic parameters were determined from linear regression of the integrated rate equation:

$$
\ln \frac{C_{\mathrm{A}}}{C_{\mathrm{A} 0}}=-\mathrm{k} t
$$

where $C_{\mathrm{A}}$ is the concentration $\left(\mathrm{mg} \mathrm{L}^{-1}\right)$ at any time $t$ (days), $C_{\mathrm{A} 0}$ is the initial concentration $\left(\mathrm{mg} \mathrm{L}^{-1}\right)$ and $\mathrm{k}$ is the first-order rate constant.

\section{Anaerobic co-digestion trials}

Co-digestion trials were performed in a $6 \mathrm{~L}$ Continuously Stirred Tank Reactor (CSTR) (working volume of $4 \mathrm{~L}$ ) at $37 \pm 2{ }^{\circ} \mathrm{C}$. Figure 1 presents a scheme of the benchscale reactor.

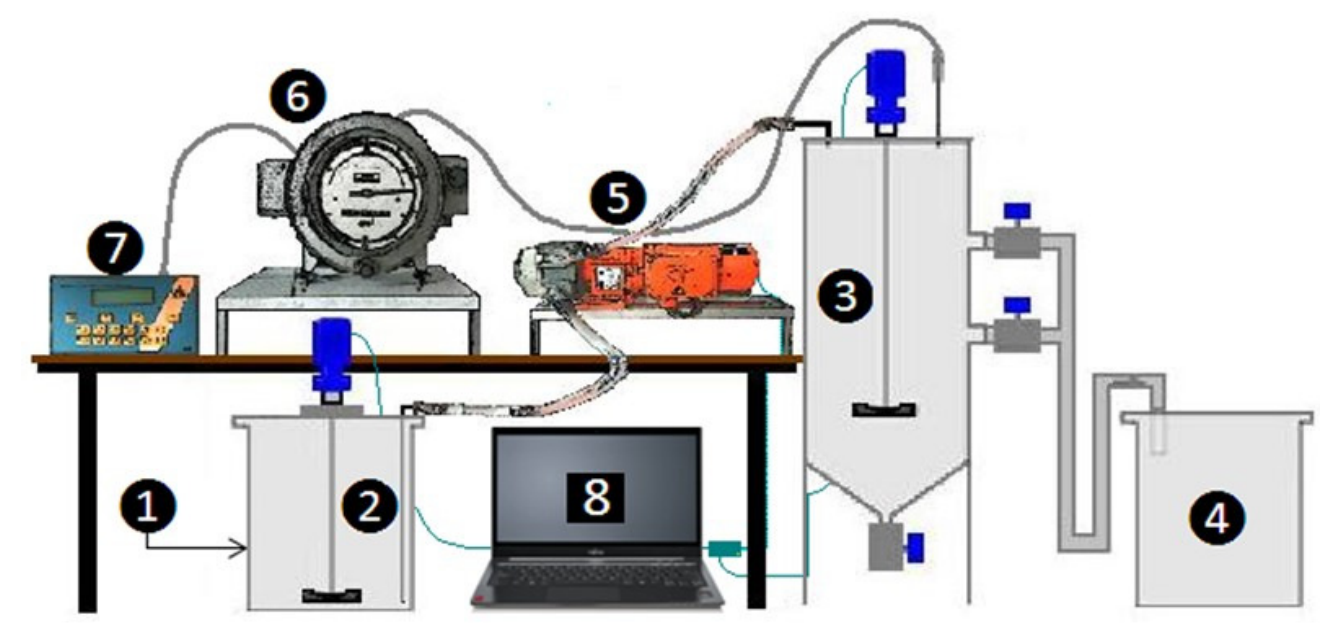

Figure 1. Simplified scheme of the anaerobic bench-scale reactor: Feed tank (1); Stirrer (2); CSTR (3); Digestate tank (4); Feed pump (5); Gas flow meter (6); Gas analyzer (7); PLC (8)

The reactor was continuously operated with PSW until steady state conditions were achieved (data not shown), with a Hydraulic Retention Time (HRT) of 10 days. After this 
period a mono-digestion trial using only PSW (Phase I) was conducted during 20 days (2 HRT), after which fresh Duckweed Biomass (DB) was included (Phase II) as cosubstrate, using a mixture of $100 \mathrm{~g}$ of DB in $1 \mathrm{~L}$ of PSW. Phase II lasted 40 days (4 HRT).

The most important physico-chemical parameters, such as: pH, EC, TS, VS, COD, TKN and $\mathrm{NH}_{4}{ }^{+}-\mathrm{N}$ were monitored in feedstock. Process performance was controlled by monitoring the Organic Loading Rate (OLR), Gas Production Rate (GPR), biogas quality and Specific Methane Production (SMP). GPR was measured daily (Contigea Schlumberger instruments gas meter) and biogas quality [composition in Methane $\left(\mathrm{CH}_{4}\right)$, Carbon dioxide $\left(\mathrm{CO}_{2}\right)$ and Hydrogen sulphide $\left(\mathrm{H}_{2} \mathrm{~S}\right)$ was determined weekly by a portable equipment (GAS DATA Multifunction analyser)].

\section{RESULTS AND DISCUSSION}

\section{Swine wastewater characterisation}

Physic-chemical characterisation of PSW is presented in Table 1. Comparing the results obtained with those mentioned in the literature, it can be seen that for most parameters the average values are within the range of values mentioned by other authors pH 7.3-8.3; EC 7.98-19.1 $\mathrm{mScm}^{-1}$; TS 12.2-28.9 $\mathrm{g} \mathrm{L}^{-1}$; COD 7.1-28 $\mathrm{g} \mathrm{L}^{-1}$; TKN 0.9-2.5 $\mathrm{g} \mathrm{L}^{-1} ; \mathrm{NH}_{4}^{+}-\mathrm{N}$ 0.7-1.9 $\mathrm{g} \mathrm{L}^{-1}[23,24]$. Regarding total solids, it should be mentioned that the characterised slurry has a content 2-3 times lower than that found by other authors $[23,25]$ probably due to an inefficient use of water.

\section{Duckweed growth and nutrient removal}

The temperature and $\mathrm{pH}$ of the culture solution was $25.0 \pm 0.7^{\circ} \mathrm{C}$ and $7.37 \pm 0.42$, respectively. The biomass production revealed a lag phase of two days followed by an exponential growth until tenth day, beyond which no growth was observed (Figure 2). Similar results were found by Yin et al. [19], obtaining the maximum biomass production at day 12, with a photoperiod of 12:12. Also, they reported a 7,500 lux as the optimum light intensity for duckweed growth. Although, the biomass yields of small-leaf floating macrophytes are quite lower than for large-leaf floating aquatic macrophyte such as Eichhornia crassipes or Piscia stratiotes [26], the ability of duckweeds to assimilate nutrients from culture medium has been reported by different authors as comparable $[4,27]$.

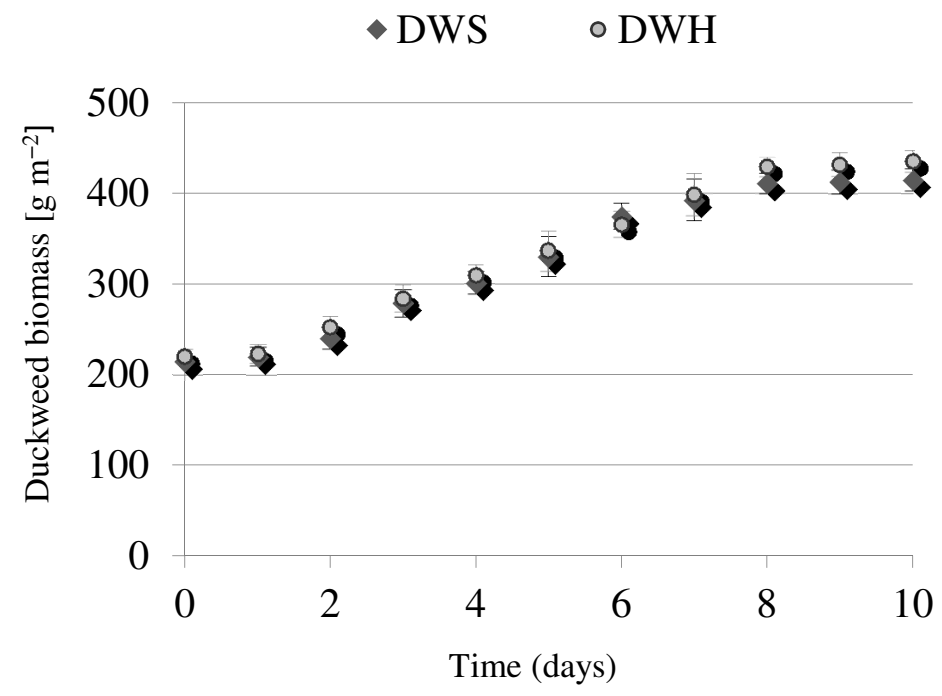

Figure 2. Comparison of duckweed Density in Swine Slurry (DWS) and Hoagland solution (DWH), during assays 
The change of nutrient in the swine wastewater container covered with $L$. minor indicated that there was organic matter, $\mathrm{N}$ and $\mathrm{P}$ reduction in the culture medium (Figure 3) during the lag phase of growth, which may be related to the accumulation of nutrients in the cells, as reported by Cheng et al. [7].
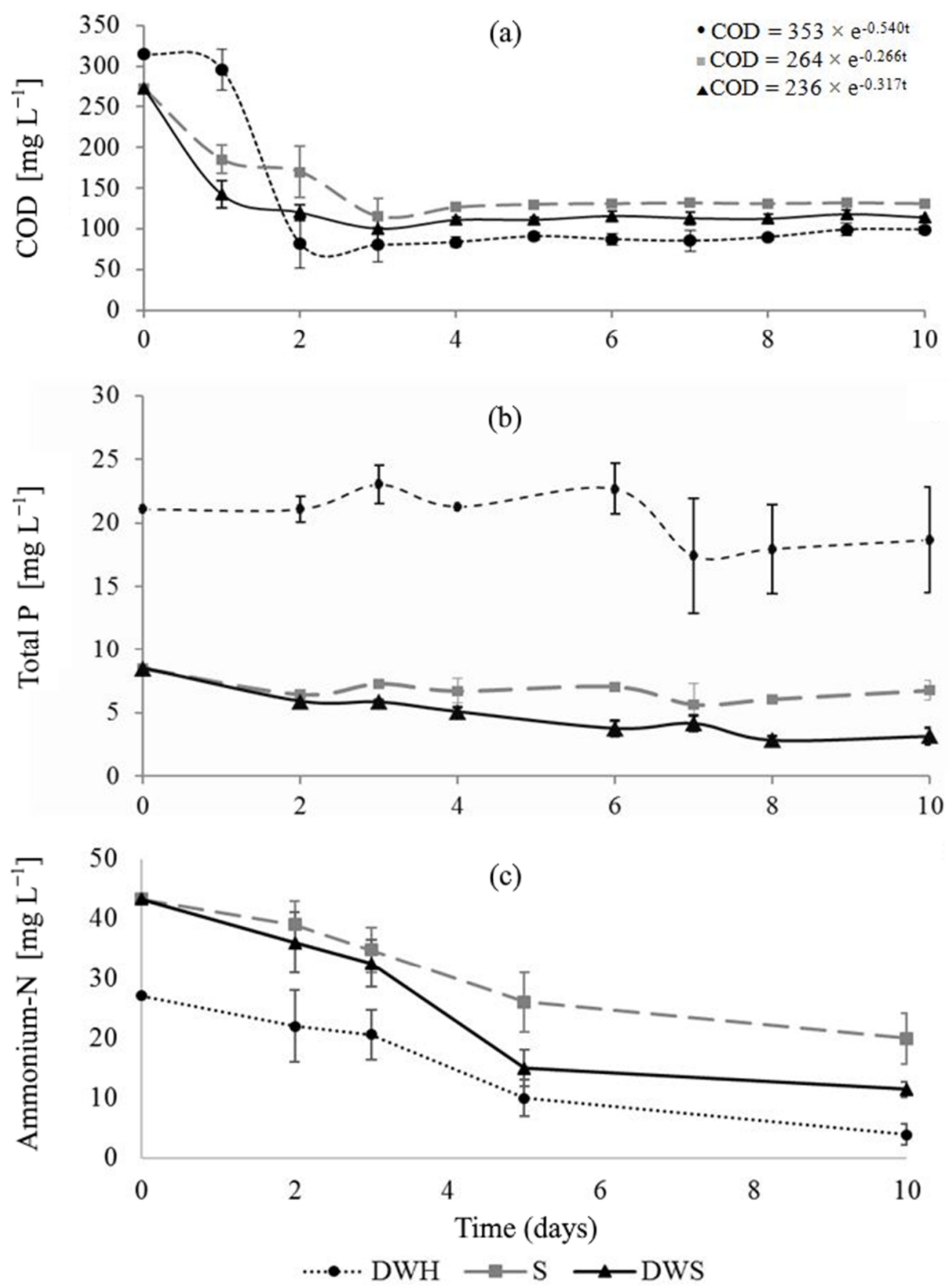

Figure 3. Removal of COD (a); Total P (b); Ammonium-N (c) from 4\% Swine Slurry without Duckweed (S), 4\% Swine Slurry with Duckweed (DWS) and Hoagland Solution with Duckweed (DWH)

The behaviour of organic matter, determined as COD concentration, in the growth assays containing duckweed and control followed first-order kinetics, with a reaction rate constant $\mathrm{k}$ of 0.267 and $0.317 \mathrm{day}^{-1}$ (Figure 3a). Initially, there was a sharp decrease in organic matter content, which remained roughly constant after 3 days of growth. These results indicate the existence of readily biodegradable organic matter, since the slope $d(\mathrm{COD}) / d t$ of the consumption of organic matter is rather sharp curve. In swine 
wastewater, about $58.9 \%$ of COD was removed by duckweed system over $52.8 \%$ by control system. Typically, part of the organic matter is degraded due to the activity of microorganisms and algae, which proliferate in the culture medium. The introduction of duckweed in the system may have created synergies, contributing to the improvement of the treatment process.

The reduction of phosphorus concentration throughout the growing DWS (Figure 3b), was about $66 \%$ compared to $20 \%$ of the S assay. The removal of phosphorus in the control assay may be due to the growth of microorganisms and algae that utilize phosphorus in their growths, although in small quantities. Vermaat and Hanif [28] conducted several batch growths of macrophytes plants, during 12 days, in domestic wastewater and found that Azolla and Lemna were responsible for about $18 \%$ and $56 \%$ removal of total phosphorus, respectively. The phosphorus removal rate due to plant uptake was $3.47 \mathrm{mg}$ $\mathrm{P} \mathrm{m}^{-2} \mathrm{day}^{-1}$. These results show that under test conditions, Lemna has a great capacity to remove this nutrient.

Regarding nitrogen removal (Figure 3c) during the first 3 days, no major differences between DWS and control S were observed. Conversely, after 10 days of culture, $74 \%$ of $\mathrm{NH}_{4}{ }^{+}-\mathrm{N}$ was removed from the DWS assay compared to $45 \%$ in control. These results are in accordance to Monselise and Kost [29], who reported that L. minor removed nitrogen mainly in the form of ammonia.

Although Debusk et al. [30] reports a 54\% removal of nitrogen containing hyacinth lagoon, Oron [31] found an efficiency of removal of ammonia in the range of 40 to $90 \%$ depending on the hydraulic retention time in the tank containing Lemna. Zimmo [32] also evaluated the duckweed performance to remove nutrients and obtained an ammonia removal efficiency of 26-41\%, depending on the $\mathrm{pH}$, which reveals somewhat lower than that obtained in this study. Nitrification was the other pathway for $\mathrm{NH}_{4}{ }^{+}-\mathrm{N}$ removal, which resulted in the increase of $\mathrm{NO}_{3}^{-}-\mathrm{N}$ concentration to $1.21 \mathrm{mg} \mathrm{m}^{-2}$ day ${ }^{-1}$, like reported by [4].

Plant tissue $\mathrm{N}$ and $\mathrm{P}$ contents by the end of the experiments showed $44.8 \mathrm{~g} \mathrm{~N} \mathrm{~kg}^{-1}$ of dry wt and $11.2 \mathrm{~g} \mathrm{P} \mathrm{kg}^{-1}$ dry wt, which are among the expected results for the [27]. The highest observed growth rate achieved by L. minor was $140 \pm 14 \mathrm{mg} \mathrm{N} \mathrm{m}^{-2} \mathrm{day}^{-1}$ in DWS (Table 2) was slightly lower than in DWH but no significant differences were attained. Although the authors assert that the productivity of biomass can be influenced by the composition of culture medium [33] or wastewater characteristics [34], results have shown that PSW, at $4 \%$ of dilution, are suitable for growing duckweed.

The study was conducted in lab scale but the scale-up seems to be promising. Based on a facultative pond with $10,000 \mathrm{~m}^{2}$, and considering productivity obtained as the annual

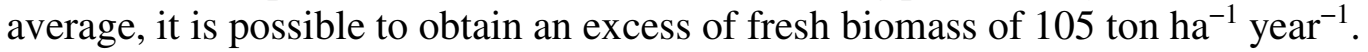

Table 2. Biomass yield an nutrients removal rates

\begin{tabular}{cccc}
\hline Assay & $\begin{array}{c}\text { Biomass yield } \\
{\left[\mathrm{g}_{\text {DW m }}{ }^{-2} \mathrm{day}^{-1}\right]}\end{array}$ & $\begin{array}{c}\mathrm{N} \mathrm{removal} \mathrm{rate} \\
{\left[\mathrm{mg} \mathrm{N} \mathrm{m}^{-2} \text { day }^{-1}\right]}\end{array}$ & $\begin{array}{c}\text { P removal rate } \\
{\left[\mathrm{mg} \mathrm{P} \mathrm{m}^{-2} \text { day }^{-1}\right]}\end{array}$ \\
\hline DWH & $3.56 \pm 0.19 \mathrm{a}$ & $161 \pm 22 \mathrm{a}$ & $4.03 \pm 0.50 \mathrm{a}$ \\
DWS & $3.10 \pm 0.25 \mathrm{a}$ & $140 \pm 14 \mathrm{a}$ & $3.47 \pm 0.64 \mathrm{a}$ \\
\hline
\end{tabular}

\section{Biomass valorisation by anaerobic co-digestion}

Many studies have focused on the application of Lemna minor in the treatment of wastewater, recovery of nutrients, and use as a food ingredient for animals, but none addressed these aspects simultaneously. In this study, an integrated approach of biomass production and valorisation, nutrient recovery from wastewater and production of a renewable energy is assessed. Table 3 presents the feed used in Phase I (mono-substrate) 
and Phase II (co-digestion). Table 4 summarizes the behaviour of performance parameters along the two AD phases.

Table 3. Pre-treated Swine Wastewater (PSW) and feed mixture characteristics

\begin{tabular}{ccc}
\hline Parameter & PSW & PSW: DB \\
\hline $\mathrm{pH}$ & $7.8 \pm 0.1$ & $7.8 \pm 0.1$ \\
$\mathrm{EC}\left[\mathrm{m} \mathrm{Scm}^{-1}\right]$ & $9.5 \pm 1.5$ & $9.5 \pm 1.2$ \\
$\mathrm{TS}\left[\mathrm{g} \mathrm{L}^{-1}\right]$ & $7.6 \pm 0.8$ & $10.4 \pm 1.2$ \\
$\mathrm{VS}\left[\mathrm{g} \mathrm{L}^{-1}\right]$ & $4.6 \pm 0.3$ & $6.7 \pm 0.9$ \\
$\mathrm{COD}\left[\mathrm{g} \mathrm{L}^{-1}\right]$ & $8.3 \pm 0.8$ & $9.9 \pm 1.5$ \\
$\mathrm{TKN}\left[\mathrm{g} \mathrm{L}^{-1}\right]$ & $1.2 \pm 0.1$ & $1.4 \pm 0.2$ \\
$\mathrm{NH}_{4}^{+}-\mathrm{N}\left[\mathrm{g} \mathrm{L}^{-1}\right]$ & $0.9 \pm 0.1$ & $1.2 \pm 0.2$ \\
$\mathrm{C} / \mathrm{N}$ & 2.2 & 2.8 \\
\hline
\end{tabular}

As it can be seen from Table 3, the feed mixture leads to $46 \%$ increase in VS and $20 \%$ in $\mathrm{COD}$, resulting in a $27 \%$ increase in $\mathrm{C} / \mathrm{N}$ ratio what may enhance methane yield production in the co-digestion phase due to a slightly more favorable medium for efficient microbial growth.

Table 4. Behaviour of performance parameters during the $\mathrm{AD}$ phases

\begin{tabular}{ccc}
\hline Parameter & Phase I & Phase II \\
\hline OLR $\left[\mathrm{g} \mathrm{COD} \mathrm{L}^{-1} \mathrm{~d}^{-1}\right]$ & $0.83 \pm 0.21$ & $0.99 \pm 0.32$ \\
GPR $\left[\mathrm{L} \mathrm{d}^{-1}\right]$ & $0.62 \pm 0.05$ & $0.86 \pm 0.07$ \\
Biogas quality $\left[\% \mathrm{CH}_{4}\right]$ & $50.0 \pm 0.2$ & $60.0 \pm 0.3$ \\
SMP $\left[\mathrm{mL} \mathrm{CH}_{4} \mathrm{~g}^{-1} \mathrm{COD}\right]$ & $93.0 \pm 0.5$ & $131.0 \pm 0.8$ \\
\hline
\end{tabular}

Results presented in Table 4 show that the introduction of duckweed leads to a $20 \%$ increase in OLR, followed by a $40 \%$ increase in GPR. Regarding SMP, the same trend was observed, with a $41 \%$ increase with co-digestion. This fact is in accordance with the slight increase in $\mathrm{C} / \mathrm{N}$ ratio favouring conversion of organic matter to biogas.

The results obtained for SMP, 93.0 $\mathrm{mL} \mathrm{CH}_{4} \mathrm{~g}^{-1} \mathrm{COD}\left(168 \mathrm{~mL} \mathrm{CH}_{4} \mathrm{~g}^{-1} \mathrm{VS}\right)$ and $131 \mathrm{~mL} \mathrm{CH}_{4} \mathrm{~g}^{-1} \mathrm{COD}\left(193 \mathrm{~mL} \mathrm{CH}_{4} \mathrm{~g}^{-1} \mathrm{VS}\right)$, respectively for Phase I and II, are lower than the ones reported by other authors. For example Riaño et al. [35] reported a SMP of $256 \mathrm{~mL} \mathrm{CH}_{4} \mathrm{~g}^{-1} \mathrm{COD}$ for AD of swine wastewater with a HRT of 12 days. Panichnumsin et al. [36] obtained $217 \mathrm{~mL} \mathrm{CH} \mathrm{g}^{-1} \mathrm{VS}$ by co-digesting cassava pulp with swine wastewater with a HRT of 15 days. Molinuevo-Salces et al. [37] studied the effect of adding vegetable processing wastes as a co-substrate in $\mathrm{AD}$ of swine wastewater, also assessing the impact of two different HRT (25 and 15 days) on SMP. They were able to conclude that the reduction of HRT from 25 to 15 days led to an increase of SMP from 90 to $201 \mathrm{~mL} \mathrm{CH}_{4} \mathrm{~g}^{-1} \mathrm{VS}$, for swine wastewater alone, and from 277 to $285 \mathrm{CH}_{4} \mathrm{~g}^{-1} \mathrm{VS}$ for swine wastewater and vegetable processing waste. This fact indicates that the reduction of HRT lead to an increase of OLR and consequently a higher amount of substrate available for microorganisms. Nevertheless, results achieved are in accordance with those found in literature that indicated that anaerobic co-digestion could increase $\mathrm{CH}_{4}$ production of manure digestion [38] depending on the operating conditions and the co-substrates used $[39,40]$. Although further studies are required to better understand the synergetic effect of duckweed as co-substrate, it was shown that it is a potential bioenergy source having excellent growth behaviour in swine wastewater and nutrient removal 
efficiency. Furthermore, the optimization between depuration efficiency, mainly nitrogen removal, and the $\mathrm{C} / \mathrm{N}$ ratio suitable for $\mathrm{AD}$ should be addressed in future studies in order to establish the best strategy for the integrated approach at farm scale.

As the experimental design took into consideration the swine wastewater management practices carried out in a swine production farm and also the characteristics of the lagooning system implemented, it can be expected that the lab-scale study described will be applicable at a full-scale. Furthermore, some of the practical constraints of growing duckweed in a batch container will be avoided at full-scale continuous mode.

The holistic conceptual approach would include depuration of swine wastewater by growing duckweed, enhancing energy production from co-digestion of duckweed biomass and swine wastewater and using the surplus of duckweed biomass to replace other protein sources for animal feed. This last aspect is also worth exploring as feed is one of the main costs of swine production and highly contributes to the economic crisis presently affecting the sector.

\section{CONCLUSION}

Lemna minor was grown in swine wastewater and effectively removed $\mathrm{N}$ and $\mathrm{P}$, producing valuable biomass. The highest observed growth rate was $3.10 \pm 0.25 \mathrm{gDw} \mathrm{m}^{-2}$ day $^{-1}$ and the $\mathrm{N}$ and $\mathrm{P}$ uptake rates were $140 \mathrm{mg} \mathrm{m}^{-2}$ day $^{-1}$ and $3.47 \mathrm{mg} \mathrm{m}^{-2}$ day $^{-1}$, respectively. The increase in nitrates in swine wastewater was about $1.21 \mathrm{mg} \mathrm{m}^{-2}$ day $^{-1}$. The average removal efficiencies observed during the depuration assays (DWS) were $58.9 \pm 2.0 \%$ for COD, $66.1 \pm 2.7 \%$ for $\mathrm{P}$ and $74.0 \pm 2.1 \%$ for $\mathrm{NH}_{4}{ }^{+}-$ $\mathrm{N}$. Anaerobic co-digestion trials showed that there is a clear improvement in gas production rate $(40 \%)$ and methane specific production $(41 \%)$ when L. minor is used in the feed mixture compared to mono-substrate digestion. The experiment demonstrated that constructed floating wetlands can be used for treating swine wastewater and growing duckweed biomass, mitigating the environmental impact caused by livestock production and producing an added-value by-product. The suggested integrated approach could be implemented at farm-scale for swine wastewater management, growing L. minor in swine wastewater at the last lagoon (facultative) and using the resulting biomass for anaerobic co-digestion. The digestate from $\mathrm{AD}$ and the depurated swine wastewater could potentially be used as a source of nutrients and water in the surrounding agricultural fields. This vision is in line with the most recent trends regarding resources and waste valorisation, aiming at promoting a circular economy, recovering energy, water and nutrients from swine wastewater.

\section{NOMENCLATURE}

$\begin{array}{llc}C_{\mathrm{A}} & \text { concentration } & {\left[\mathrm{mg} \mathrm{L}^{-1}\right]} \\ C_{\mathrm{A} 0} & \text { initial concentration } & {\left[\mathrm{mg} \mathrm{L}^{-1}\right]} \\ \mathrm{k} & \text { first-order rate constant } & {\left[\mathrm{day}^{-1}\right]}\end{array}$

\section{Abbreviations}

$\begin{array}{ll}\text { AD } & \text { Anaerobic Digestion } \\ \text { COD } & \text { Chemical Oxygen Demand } \\ \text { CSTR } & \text { Continuously Stirred Tank Reactor } \\ \text { DB } & \text { Duckweed Biomass } \\ \text { DWS } & \text { Duckweed in Swine Wastewater } \\ \text { DWH } & \text { Duckweed in Hoagland Solution } \\ \text { DW } & \text { Dry Weight } \\ \text { EC } & \text { Electric Conductivity } \\ \text { FW } & \text { Fresh Weight }\end{array}$




\begin{tabular}{ll}
\hline GHG & Greenhouse Gas \\
GPR & Gas Production Rate \\
HRT & Hydraulic Retention Time \\
OLR & Organic Loading Rate \\
PSW & Pre-treated Swine Wastewater \\
S & Pre-treated Swine Wastewater, diluted at 4\% \\
SMP & Specific Methane Production \\
SW & Swine Wastewater \\
TKN & Total Kjeldahl Nitrogen \\
TS & Total Solids \\
VS & Total Volatile Solids
\end{tabular}

\section{REFERENCES}

1. Martinez, J., Dabert, P., Barrington, S. and Burton, C. Livestock Waste Treatment Systems for Environmental Quality, Food Safety and Sustainability, Bioresour. Technol., Vol. 100, No. 22, pp 5527-5536, 2009, http://dx.doi.org/10.1016/j.biortech.2009.02.038

2. Fragoso, R., Duarte, E. and Paiva, J. Contribution of Coagulation-flocculation Process for a More Sustainable Pig Slurry Management, Water Air Soil Poll., Vol. 226, No. 5, 131 p, 2015, http://dx.doi.org/10.1007/s11270-015-2388-4

3. Hutchings, N. J., Hoeve, M., Jensen, R., Bruun, S. and Søtoft, L. F., Modelling the Potential of Slurry Management Technologies to Reduce the Constraints of Environmental Legislation on Pig Production, J. Environ. Manag., Vol. 130, pp 447-456, 2013, http://dx.doi.org/10.1016/j.jenvman.2013.08.063

4. Xu, J. and Shen, G., Growing Duckweed in Swine Wastewater for Nutrient Recovery and Biomass Production, Bioresour. Technol., Vol. 102, No. 2, pp 848-853, 2011, http://dx.doi.org/10.1016/j.biortech.2010.09.003

5. Xiao, Y., Fang, Y., Jin, Y. L., Zhang, G. H. and Zhao, H., Culturing Duckweed in the Field for Starch Accumulation, Ind. Crops Prod., Vol. 48, pp 183-190, 2013, http://dx.doi.org/10.1016/j.indcrop.2013.04.017

6. Cheng, J. J. and Stomp, A. M., Growing Duckweed to Recover Nutrients from Wastewaters and for Production of Fuel Ethanol and Animal Feed, Clean - Soil, Air, Water, Vol. 37, No. 1, pp 17-26, 2009, http://dx.doi.org/10.1002/clen.200800210

7. Cheng, J., Bergmann, B. A., Classen, J. J. and Howard, J. W., Nutrient Recovery from Swine Lagoon Water by Spirodela Punctata, Bioresour. Technol., Vol. 81, No. 1, pp 81-85, 2002, http://dx.doi.org/10.1016/S0960-8524(01)00098-0

8. Rusoff, L. L., Blakeney, E. W. and Culley, D. D., Duckweeds (Lemnaceae Family): A Potential Source of Protein and Amino Acids, J. Agr. Food Chem., Vol. 28, No. 4, pp 848-850, 1980, http://dx.doi.org/10.1021/jf60230a040

9. Appenroth, K. J., Borisjuk, N. and Lam, E., Telling Duckweed Apart: Genotyping Technologies for the Lemnaceae, Chinese Journal of Applied and Environmental Biology, Vol. 19, No. 1, pp 1-10, 2013, http://dx.doi.org/10.3724/SP.J.1145.2013.00001

10. Stomp, A. M., The Duckweeds: A Valuable Plant for Biomanufacturing, Biotechnol. Annu. Rev., Vol. 11, pp 69-99, 2005, http://dx.doi.org/10.1016/S1387-2656(05)110023

11. Adhikari, U., Harrigan, T. and Reinhold, D. M., Use of Duckweed-based Constructed Wetlands for Nutrient Recovery and Pollutant Reduction from Dairy Wastewater, Ecol. Eng., Vol. 78, pp 6-14, 2015, http://dx.doi.org/10.1016/j.ecoleng.2014.05.024

12. Vander Steen, P., Brenner, A. and Oron, G., An Integrated Duckweed and Algae Pond System for Nitrogen Removal and Renovation, Water Sci. Technol., Vol. 38, pp 335-343, 1998, http://dx.doi.org/10.1016/S0273-1223(98)00419-3 
13. Sekomo, C. B., Rousseau, D. P. L., Saleh, S. A. and Lens, P. N. L., Heavy Metal Removal in Duckweed and Algae Ponds as a Polishing Step for Textile Wastewater Treatment, Ecol. Eng., Vol. 44, pp 102-110, 2012, http://dx.doi.org/10.1016/j.ecoleng.2012.03.003

14. El-Shafai, S. A., El-Gohary, F. A., Nasr, F. A., vander Steen, N. P. and Gijzen, H. J., Nutrient Recovery from Domestic Wastewater using a UASB-duckweed Ponds System, Bioresour. Technol., Vol. 98, No. 4, pp 798-807, 2007, http://dx.doi.org/10.1016/j.biortech.2006.03.011

15. Oron, G., Duckweed Culture for Wastewater Renovation and Biomass Production, Agric. Water Manag., Vol. 26, No. 1-2, pp 27-40, 1994, http://dx.doi.org/10.1016/0378-3774(94)90022-1

16. Appenroth, K. J., Sree, K. S, Fakhoorian, T. and Lam, E., Resurgence of Duckweed Research and Applications: Report from the $3^{\text {rd }}$ International Duckweed Conference, Plant Mol. Biol., Vol. 89, No. 6, pp 647-654, 2015, http://dx.doi.org/10.1007/s11103015-0396-9

17. Xu, J., Zhao, H., Stomp, A-M. and Cheng, J. J., The Production of Duckweed as a Source of Biofuels, Biofuels, Vol. 15, No. 3, pp 589-601, 2015.

18. Ziegler, P., Adelmann, K., Zimmer, S., Schmidt, C. and Appenroth, K. J., Relative in Vitro Growth Rates of Duckweeds (Lemnaceae) - the most Rapidly Growing Higher Plants, Plant Biology, Vol. 17, No. 1, pp 33-41, 2015, http://dx.doi.org/10.1111/plb.12184

19. Yin, Y., Yu, C., Yu, L., Zhao, J., Sun, C., Ma, Y. and Zhou, G., The Influence of Light Intensity and Photoperiod on Duckweed Biomass and Starch Accumulation for Bioethanol Production, Bioresour. Technol., Vol. 187, pp 84-90, 2015, http://dx.doi.org/10.1016/j.biortech.2015.03.097

20. APHA, AWWA, WEF, Standard Methods for the Examination of Water and Wastewater (Clesceri, L., Greenberg, A. and Eaton, A., eds.), $21^{\text {st }}$ American Public Health Association and Water Environment Federation, Washington, USA, 2005.

21. Hoagland, D. R. and Arnon, D. I., The Water-culture Method for growing Plants without Soil, California Agricultural Experiment Station Circular, Vol. 347, pp 1-32, 1950.

22. Kalra, Y. P., Handbook of Reference Methods for Plant Analysis, CRC Press Editions, 287 p, 1998.

23. Sánchez, M., González, J. L., The Fertilizer Value of Pig Slurry (I) Values depending on the Type of Operation, Bioresour. Technol., Vol. 96, No. 10, pp 1117-1123, 2005, http://dx.doi.org/10.1016/j.biortech.2004.10.002

24. Provolo, G. and Martínez-Suller, L., In Situ Determination of Slurry Nutrient Content by Electrical Conductivity, Bioresour. Technol., Vol. 98, No. 17, pp 3235-3242, 2007, http://dx.doi.org/10.1016/j.biortech.2006.07.018

25. Yagüe, M. R., Bosch-Serra, A. D. and Boixadera, J., Measurement and Estimation of the Fertiliser Value of Pig Slurry by Physicochemical Models: Usefulness and Constraints, Biosyst. Eng., Vol. 111, No. 2, pp 206-216, 2012, http://dx.doi.org/10.1016/j.biosystemseng.2011.11.013

26. Debusk, T. A., Hanisak, M. D., Williams, L. D. and Ryther, J. H., Effects of Seasonality and Plant Density on the Productivity of some Freshwater Macrophytes, Aquat. Bot., Vol. 10, pp 133-142, 1981, http://dx.doi.org/10.1016/03043770(81)90016-4

27. Zhao, Z., Shi, H., Liu, Y., Zhao, H., Su, H. and Wang, M., The Influence of Duckweed Species Diversity on Biomass Productivity and Nutrient Removal Efficiency in Swine Wastewater, Bioresour. Technol., Vol. 167, pp 383-389, 2014, http://dx.doi.org/10.1016/j.biortech.2014.06.031

28. Vermaat, J. M. and Hanif, M. K., Performance of Common Duckweed Species (Lemnaceae) and Waterfern Azolla filiculoides on different types of Wastewater, 
Water Res., Vol. 32, No. 9, pp 2569-2576, 1998, http://dx.doi.org/10.1016/S00431354(98)00037-2

29. Monselise, B. E. and Kost, D., Different Ammonium uptake, Metabolism and Detoxification Efficiencies in two Lemnaceae, Planta, Vol. 189, pp 167-173, 1993, http://dx.doi.org/10.1007/BF00195073

30. DeBusk, T. A., Reddy, K. R., Hayes, T. D. and Schwegler, Jr. B. R., Performance of a Pilot-scale Water Hyacinth-based Secondary Treatment System, J. Water Pollut. Control Fed., Vol. 61, No. 7, pp 1217-1224, 1989.

31. Oron, G., Economic Considerations in Wastewater Treatment with Duckweed for Effluent and Nitrogen Renovation, J. Water Pollut. Control Fed., Vol. 62, No. 5, pp 692-696, 1990.

32. Zimmo, O., Nitrogen Transformations and Removal Mechanisms in Algal and Duckweed Waste Stabilization Ponds, Ph. D. Thesis, International Institute for Infrastructural, Hydraulic and Environmental Engineering, Delft, The Netherlands, 2003.

33. Reddy, K. R. and DeBusk, W. F., Growth Characteristics of Aquatic Macrophytes Cultured in Nutrient-enriched Water: II, Azolla, Duckweed and Salvinia, Econ. Bot., Vol. 39, No. 2, pp 200-208, 1985, http://dx.doi.org/10.1007/BF02907846

34. Ge, X. M., Zhang, N. N., Phillips, G. C. and Xu, J. F., Growing Lemna minor in Agricultural Wastewater and Converting the Duckweed Biomass to Ethanol, Bioresour. Technol., Vol. 124, pp 485-488, 2012, http://dx.doi.org/10.1016/j.biortech.2012.08.050

35. Riaño, B., Molinuevo, B. and García-González, M. C., Potential for Methane Production from Anaerobic Co-digestion of Swine Manure with Winery Wastewater, Bioresour. Technol., Vol. 102, No. 5, pp 4131-4136, 2011, http://dx.doi.org/10.1016/j.biortech.2010.12.077

36. Panichnumsin, P., Nopharatana, A., Ahring, B. and Chaiprasert, P., Production of Methane by Co-digestion of Cassava Pulp with Various Concentrations of Pig Manure, Biomass Bioenergy, Vol. 34, No. 8, pp 1117-1124, 2010, http://dx.doi.org/10.1016/j.biombioe.2010.02.018

37. Molinuevo-Salces, B., Gonzalez-Fernández, C., Gómez, X., García-Gonzalez, M. and Morán, A., Vegetable Processing Wastes Addition to improve Swine Manure Anaerobic Digestion: Evaluation in Terms of Methane Yield and SEM Characterization, Appl. Energy, Vol. 91, No. 1, pp 36-42, 2012, http://dx.doi.org/10.1016/j.apenergy.2011.09.010

38. Ferreira, L., Duarte, E., Silva, C. and Malfeito, M., Fruit Wastes Bioconversion for Anaerobic Co-digestion with Pig Manure, Process Development for the Recycling in Decentralised Farm Scale Plants, Proceedings of the International Conference Progress in Biogas, Stuttgart, Germany, pp 135-140, 2007.

39. Soldano, M., Fabbri, C. and Piccinini, S., Co-digestion Plant in Dairy Cattle Farm in Emilia Romagna Region (Italy), Proceedings of the International Conference Progress in Biogas, Stuttgart, Germany, pp 95-99, 2007.

40. Álvarez, J. A., Otero, L. and Lema, J. M., A Methodology for Optimising Feed Composition for Anaerobic Co-digestion of Agro-industrial Wastes, Bioresour. Technol., Vol. 101, No. 4, pp 1153-1158, 2010, http://dx.doi.org/10.1016/j.biortech.2009.09.061 